Cornell Law Library

Scholarship@Cornell Law: A Digital Repository

Cornell Law Faculty Publications

$1-1-2009$

\title{
Taking a Stand on Taking the Stand: The Effect of a Prior Criminal Record on the Decision to Testify and On Trial Outcomes
}

Theodore Eisenberg

Cornell Law School, ted-eisenberg@lawschool.cornell.edu

Valerie P. Hans

Cornell Law School, valerie.hans@cornell.edu

Follow this and additional works at: http://scholarship.law.cornell.edu/lsrp_papers

Part of the Criminal Law Commons, and the Evidence Commons

\section{Recommended Citation}

Eisenberg, Theodore and Hans, Valerie P., "Taking a Stand on Taking the Stand: The Effect of a Prior Criminal Record on the Decision to Testify and On Trial Outcomes" (2009). Cornell Law Faculty Publications. Paper 90.

http://scholarship.law.cornell.edu/lsrp_papers/90 


\title{
TAKING A STAND ON TAKING THE STAND: THE EFFECT OF A PRIOR CRIMINAL RECORD ON THE DEGISION TO TESTIFY AND ON TRIAL OUTCOMES
}

\author{
Theodore Eisenberg $\mathcal{E}$ Valerie P. Hans $\dagger$
}

\begin{abstract}
This Article uses unique data from over 300 criminal trials in four large counties to study the relations between the existence of a prior criminal record and defendants testifying at trial, between defendants testifying at trial and juries' learning about criminal records, and between juries' learning about criminal records and their decisions to convict or acquit. Sixty percent of defendants without criminal records testified, compared to fortyfive percent with criminal records. For testifying defendants with criminal records, juries learned of those records in about half the cases. Juries rarely learned about criminal records unless defendants testified. After controlling for evidentiary strength and other factors, statistically significant associations exist (1) between the existence of a criminal record and the decision to testify at trial, (2) between the defendant's testifying at trial and the jury's learning about the defendant's prior record, and (3), in cases with weak evidence, between the jury's learning of a criminal record and conviction. For cases with strong evidence against defendants, learning of criminal records is not strongly associated with conviction rates. Juries appear to rely on criminal records to convict when other evidence in the case normally would not support conviction. Use of prior-record evidence may therefore lead to erroneous convictions. We also find little evidence that prior-record information influences credibility. This casts doubt on the historical justification for prior-record evidence: its presumed effect on defendant-as-witness credibility. Prosecutors and judges should consider the increased likelihood of erroneous conviction based on the use of prior convictions in decisions to prosecute and in evidentiary rulings.
\end{abstract}

$\dagger$ Theodore Eisenberg is Henry Allen Mark Professor of Law and Adjunct Professor of Statistical Sciences, Cornell University, Myron Taylor Hall, Ithaca, NY 14853; e-mail: tedeisenberg@lawschool.cornell.edu. Valerie Hans is Professor of Law, Cornell Law School, Myron Taylor Hall, Ithaca, NY 14853; e-mail: valerie.hans@cornell.edu. Drafts of this Article were presented at the 2007 Law and Society Association Meeting, Berlin, and faculty workshops at Cornell Law School, University of Illinois College of Law, and NYU School of Law. Data gathering was supported by Grant No. 98-IJ-CX-0048, National Institute of Justice, Office of Justice Programs, U.S. Department of Justice. Points of view in this document are those of the authors and do not necessarily represent the official position or policies of the U.S. Department of Justice or the National Center for State Courts. We thank Sherry Colb, Michael Heise, David Hoffman, Sally Lloyd-Bostock, Jeffrey Rachlinski, and Catherine Sharkey for comments on earlier drafts and Cornell Law School librarian Julie Jones for research assistance. 


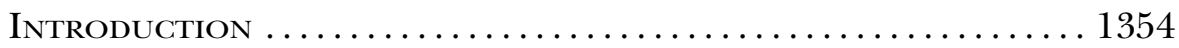

I. Prior Research on Defendant Testimony and the EFfect of Criminal Record ........................ 1357

A. Experimental Research with Mock Jurors .......... 1358

B. Research with Judges ........................ 1361

C. Prior Research with Real Juries ................. 1363

D. Some Caveats ............................. 1365

II. Data Description ............................... 1366

III. Defendant Testimony and Juries' Learning of

Criminal Record .............................. 1369

A. Defendant Testimony: Case Characteristics

Considered Separately .................... 1370

B. Juries' Learning About Prior Criminal Records: Case

Characteristics Considered Separately ............. 1373

C. Modeling Influences on the Decision to Testify and Juries' Learning About Prior Criminal Records .... 1377

IV. The Effect of Juries' Learning of Criminal Records . 1379

A. Evidentiary Strength, Conviction Rate, and

Knowledge of Record ...................... 1380

B. Regression Models of Conviction .............. 1383

C. Discussion of Results ..................... 1385

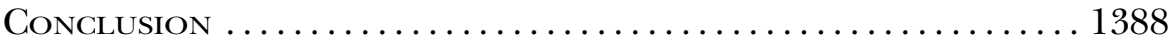

\section{INTRODUCTION}

The evidentiary treatment of a defendant's prior criminal record is one of the most important issues for the criminal justice system and for the day-to-day conduct of criminal cases. Some pressure to testify and deny guilt likely exists in almost every case. Adjudicators naturally want to hear defendants provide their own accounts of involvement or lack of involvement in crimes. Not testifying in one's own defense may influence a trial's outcome notwithstanding the Fifth Amendment's prohibition against self-incrimination. Prosecutors, until prohibited from doing so, argued that a defendant's failure to testify was evidence of guilt. ${ }^{1}$ In a less direct violation of the Fifth Amendment, prosecutors may argue that the defendant failed to rebut particular evidence, even if the only reasonable way to do so was through the defendant's testifying. ${ }^{2}$ Having a prior criminal record must be considered when a defendant is deciding whether to testify. Indeed, a

1 See, e.g., Griffin v. California, 380 U.S. 609, 610-11 (1965). Until at least 1961, the common law rule prohibiting defendants, as interested parties, from testifying on behalf of themselves remained in force in Georgia but had been abolished throughout the rest of the common law world. See Ferguson v. Georgia, 365 U.S. 570, 570, 574 (1961).

2 E.g., United States v. Cotnam, 88 F.3d 487, 497 (7th Cir. 1996). 
principal reason defendants decline to testify is the existence of prior criminal records. ${ }^{3}$

All U.S. jurisdictions allow the use of some criminal convictions to impeach the credibility of a witness. ${ }^{4}$ Indeed, the impeachment of witnesses with their prior records was permitted at common law as early as the seventeenth century. ${ }^{5}$ The existence of felony (and some other) convictions led to the inference that the witness was highly likely to lie under oath. Early on, defendants who were convicted felons were completely prohibited from taking the stand because their testimony was seen as having no credibility. Over time, the prohibition was eventually eased to permit defendants with records to testify, yet simultaneously to allow the impeachment of defendants with their prior convictions.

When to allow the fact finder to learn of a prior criminal record is an important evidentiary topic because a prior record is understandably thought to promote convictions. Evidentiary rules try to balance a defendant's interest in testifying and the prejudicial effect of impeaching a defendant's testimony using prior convictions. For example, Federal Rule of Evidence 609(a) (1) allows impeachment by prior convictions "if the court determines that the probative value of admitting this evidence outweighs its prejudicial effect to the accused." 6

3 See, e.g., Carter v. Kentucky, 450 U.S. 288, 292-93 (1981) (reciting a conference with the judge during which the defendant decided not to testify in his own defense; counsel advised the defendant during the conference that his experience indicated that impeachment with prior offenses is " 'a heavy thing; it is very serious, and I think juries take it very seriously"”); see also John H. Blume, The Dilemma of the Criminal Defendant with a Prior Record-Lessons from the Wrongfully Convicted, 5 J. Empirical Legal Stud. 477, 486, 490-91 (2008) (finding that $91 \%$ of factually innocent defendants with prior records declined to testify and that counsel in these cases reported that the primary reason was to avoid jury bias stemming from the prior record).

4 See George Fisher, Evidence 265-95 (2d ed. 2008) (discussing generally impeachment with past convictions); 3A John Henry Wigmore, Evidence in Trials at Common LAw $\$ 980$, at 828 (James H. Chadbourn rev. ed. 1970) ("It has therefore been universally acknowledged that proof of a crime by record of a judgment of conviction may be made ...." (emphasis omitted)).

5 See Fisher, supra note 4, at 266-69 (describing history and rationale of impeachment rule); Roger C. Park, Impeachment with Evidence of Prior Convictions, 36 Sw. U. L. REv. 793, 793-801 (2008) (describing history and current status of rules regarding impeachment with criminal record); H. Richard Uviller, Credence, Character, and the Rules of Evidence: Seeing Through the Liar's Tale, 42 Duke L.J. 776, 795-803 (1993) (describing history of rule regarding impeachment with criminal record); H. Richard Uviller, Evidence of Character to Prove Conduct: Illusion, Illogic, and Injustice in the Courtroom, 130 U. PA. L. REv. 845, 869-77 (1982) (describing and criticizing rules allowing impeachment with criminal record).

6 FED. R. Evid. 609(a) (1). Rule 609(a) reads:

(a) General rule. For the purpose of attacking the character for truthfulness of a witness,

(1) evidence that a witness other than an accused has been convicted of a crime shall be admitted, subject to Rule 403, if the crime was punishable by death or imprisonment in excess of one year under the law under which the witness was convicted, and evidence that an accused has been convicted 
Although questions relating to the evidentiary treatment of prior criminal records have been the object of judicial, legislative, and scholarly attention for decades, they remain of vital importance. Every year, trial judges exercise substantial discretion about the admissibility of prior records in thousands of criminal cases, and prosecutors and police are undoubtedly influenced by the existence of prior records in charging and arrest decisions. Moreover, questions of prior-record admissibility remain on legislative and public policy agendas. ${ }^{7}$ Judges' balancing of the probative value of evidence versus possible prejudice and Executive Branch decision makers' behavior should be based on the best possible information about the impact of criminal records. More importantly, the prejudicial effect of a prior criminal record may contribute to the increasingly visible problem of erroneous convictions. ${ }^{8}$

Limited empirical analysis exists of defendants' decisions to testify or of the effect of prior criminal records on trial outcomes in real jury trials. This Article uses a unique data set gathered by the National Center for State Courts (NCSC) under a grant from the National Institute of Justice (NIJ) to explore when criminal defendants testify and the effect of that testimony on jury verdicts. To summarize

of such a crime shall be admitted if the court determines that the probative value of admitting this evidence outweighs its prejudicial effect to the accused; and

(2) evidence that any witness has been convicted of a crime shall be admitted regardless of the punishment, if it readily can be determined that establishing the elements of the crime required proof or admission of an act of dishonesty or false statement by the witness.

FED. R. Evid. $609(\mathrm{a})$.

7 See, e.g., N.Y. Assem. Bill 6744, 230th Gen. Assem., Reg. Sess., §§ 16, 17 (N.Y. 2007); Thomas J. Reed, Admitting the Accused's Criminal History: The Trouble With Rule 404(b), 78 Temp. L. Rev. 201, 242-53 (2005) (examining courts' application of Rule 404(b) to admissibility of "uncharged misconduct evidence" and suggesting an alternative approach); Tamara Larsen, Comment, Sexual Violence is Unique: Why Evidence of Other Crimes Should Be Admissible in Sexual Assault and Child Molestation Cases, 29 Hamline L. Rev. 177 (2006).

8 See Samuel R. Gross et al., Exonerations in the United States 1989 Through 2003, 95 J. Crim. L. \& Criminology 523, 523-24 (2005) (reporting 340 exonerations from 1989 through 2003); Samuel R. Gross \& Barbara O'Brien, Frequency and Predictors of False Conviction: Why We Know So Little, and New Data on Capital Cases, 5 J. Empirical Legal Stud. 927, 956 (2008); Talia Roitberg Harmon, Predictors of Miscarriages of Justice in Capital Cases, 18 Just. Q. 949, 949-50 (2001) (“Capital punishment and wrongful convictions are receiving increased nationwide media attention.”); Talia Roitberg Harmon \& William S. Lofquist, Too Late for Luck: A Comparison of Post-Furman Exonerations and Executions of the Innocent, 51 Crime \& Deline. 498, 509-10 (2005); Tony G. Poveda, Estimating Wrongful Convictions, 18 Just. Q. 689, 689-90 (2001) (discussing recent scholarship on the extent of wrongful convictions); Robert J. Ramsey \& James Frank, Wrongful Conviction: Perceptions of Criminal Justice Professionals Regarding the Frequency of Wrongful Conviction and the Extent of System Errors, 53 Crime \& Deline. 436, 436-37 (2007); The Innocence Project, Facts on Post-Conviction DNA Exonerations, http://www.innocenceproject.org/Content/351.php\# (last visited Mar. 23, 2009). For an innovative effort to assess trial accuracy, see Bruce D. Spencer, Estimating the Accuracy of Jury Verdicts, 4 J. EMPIRICAL Legal STud. 305 (2007). 
our findings, $60 \%$ of defendants without criminal records testified, compared to $45 \%$ with criminal records. For testifying defendants with criminal records, juries learned of those records in about half the cases. Juries rarely learned about criminal records unless defendants testified. Statistically significant associations exist (1) between the existence of a criminal record and the decision to testify at trial, (2) between the defendant's testifying at trial and the jury's learning about the defendant's prior record, and (3), in cases with weak evidence, between the jury's learning of a criminal record and conviction. For cases with strong evidence against defendants, learning of criminal records is not associated with conviction rates. Juries appear to rely on criminal records to convict when other evidence in the case normally would not support conviction. The effect in otherwise weak cases is substantial and can increase the probability of conviction to over $50 \%$ when the probability of conviction in similar cases without criminal records is less than $20 \%$. We find no evidence that priorrecord evidence influences credibility. Given growing concern about the risk of erroneous convictions, judges, prosecutors, and police should consider this information in making decisions relating to prior criminal records.

Part I of this Article reviews prior related research, and Part II describes the data. Part III reports the results relating to defendants' testifying and juries' learning of criminal records. Part IV reports on the association between juries' learning of criminal records and conviction rates. The Article concludes with a discussion of policy implications.

Prior Research on Defendant Testimony and the EFFEct OF Criminal Record

From a theoretical perspective, there are several ways in which knowledge of a criminal record might affect a decision maker. ${ }^{9}$ First, such knowledge could function as the legal rules governing its use suggest it usually should, by affecting the credibility of the defendant as a witness in the proceedings. The limiting instruction that typically accompanies the provision of criminal-record information notes that the record should be used in assessing the defendant's credibility rather than inferring the defendant's guilt in the present offense. ${ }^{10}$ Second, a decision maker might use a defendant's criminal record to categorize the defendant as a bad person, a person of poor character. In other words, a negative halo effect might operate. Indeed, studies

9 See Valerie P. Hans \& Anthony N. Doob, Section 12 of the Canada Evidence Act and the Deliberations of Simulated Juries, 18 CRIM. L.Q. 235, 237-38 (1976).

10 See FED. R. Evid. 609. 
of social perception and cognition show that observers who learn that an individual has one negative characteristic or trait are apt to generalize and assume that the person has other bad characteristics or traits. ${ }^{11}$ Third, the meaning of the evidence might change. Meaning is constructed taking context into account. Evidence that seems inconclusive against a defendant with no record of wrongdoing may appear to be more damning when jurors learn of the defendant's criminal past. ${ }^{12}$ Thus, the weight and significance of the evidence in a case may change as a function of knowledge about a defendant's criminal record. Finally, the threshold for conviction, or the subjective burden of proof, may differ for defendants with and without criminal records. Jurors may be willing to convict on less evidence if the defendant has a criminal past. Thus, what constitutes reasonable doubt may be interpreted more expansively by jurors if the defendant appears to have no record.

\section{A. Experimental Research with Mock Jurors}

Several experimental studies have examined the possible negative effects of a defendant's criminal record on jury decision making. Using a mock jury paradigm in which research participants are given case evidence, the studies divide participants so that some learn about the defendant's criminal record while others do not. Or, the type of criminal record is varied. Comparing responses of these groups of participants provides insight into the impact of knowledge of a criminal record.

Most of the experimental studies show that knowledge of a defendant's criminal record has statistically significant biasing effects on jurors' guilt perceptions and verdicts. British researchers A.P. Sealy and W.R. Cornish conducted one of the earliest experiments testing the impact of a defendant's criminal record. ${ }^{13}$ At the time, a defendant's criminal record was generally inadmissible in British courts. ${ }^{14}$ Community members listened to a tape recording of a case of either theft or rape, made individual judgments, and then deliberated to reach a group verdict. ${ }^{15}$ The case facts were designed to be ambiguous so that either verdict could be justified. There were four conditions in the experiment: a control condition with no information about the defendant's criminal record; a condition in which a previous record for a similar offense was disclosed; a condition in which a dissimilar record

11 See Hans \& Doob, supra note 9, at 237-38; see also Susan T. Fiske \& Shelley E.

Taylor, Social Cognition: From Brains to Culture 95-96 (2d ed. 2008).

12 See Hans \& Doob, supra note 9, at 238.

13 L.S.E. Jury Project, Juries and the Rules of Evidence, 1973 CRIM. L. REv. 208.

14 Id. at 211.

15 Id. 
was disclosed; and a similar-offense condition in which the judge gave instructions to disregard the record. The researchers found an increase in the proportion of individual mock jurors' judgments of guilt when they learned of a defendant's previous record for crimes similar to that charged, although the effect declined slightly when they were told to disregard the record. Introducing a dissimilar conviction did not bias mock jurors against the defendant; in fact, the proportion voting guilty declined somewhat compared to the control condition. ${ }^{16}$

The basic finding of greater convictions if jurors learn of defendants' previous records for similar crimes has been replicated in subsequent studies. ${ }^{17}$ In addition, other experimental work has shed light on the likely mechanisms by which criminal-record information produces a greater likelihood of conviction. Valerie Hans and Anthony Doob transcribed mock jury deliberations and found that jurors who knew of a defendant's record were more apt to begin the deliberation with pro-prosecution statements, a result that suggests that they were more confident in their negative assessment of the defendant's case. ${ }^{18}$ These juries more often described the evidence as strong and more frequently brought up damaging evidence during deliberations. In contrast, juries that did not learn of the defendant's record were more likely to discredit the prosecution evidence against the defendantfor example, by describing problems with eyewitness accounts, biased police lineups, or the limits of circumstantial evidence. Jurors more often mentioned how to interpret reasonable doubt in juries that knew about the defendant's record. Hans and Doob argue that jurors interpreted the case evidence itself differently as a result of knowing

$16 I d$. at 222.

17 See A.N. Doob \& H.M. Kirshenbaum, Some Empirical Evidence on the Effect of s. 12 of the Canada Evidence Act upon an Accused, 15 CRIM. L.Q. 88, 93-95 (1972) (finding that a similar record increased convictions and that a limiting instruction had no beneficial effect); Edith Greene \& Mary Dodge, The Influence of Prior Record Evidence on Juror Decision Making, 19 LAw \& Hum. BeHAv. 67, 76 (1995) (finding that mock jurors were more likely to convict if they learned of a prior conviction, compared to no conviction information or information about a prior acquittal); Hans \& Doob, supra note 9, at 251 (finding that deliberating groups were more likely to convict if they learned of a defendant's similar criminal record); Sally Lloyd-Bostock, The Effects on Juries of Hearing About the Defendant's Previous Criminal Record: A Simulation Study, 2000 CRIM. L. REv. 734, 753-55 (finding that recent similar convictions increased the likelihood of conviction and dissimilar convictions showed a comparative decline); Roselle L. Wissler \& Michael J. Saks, On the Inefficacy of Limiting Instructions: When Jurors Use Prior Conviction Evidence to Decide on Guilt, 9 Law \& Hum. BeHav. 37, 47 (1985) (finding that similar records increased convictions compared to no prior convictions and that defendants with previous convictions for perjury and dissimilar crimes were convicted at intermediate rates); see also Eugene Borgida \& Roger Park, The Entrapment Defense: Juror Comprehension and Decision Making, 12 Law \& Hum. BEHAv. 19, 32 (1988) (finding that prior records increased convictions if entrapment was defined narrowly); Sarah Tanford \& Michele Cox, The Effects of Impeachment Evidence and Limiting Instructions on Individual and Group Decision Making, 12 LAW \& Hum. BeHAv. 477, 488 (1988) (finding that impeachment evidence influences decision making in legally impermissible ways).

18 Hans \& Doob, supra note 9, at 244. 
the defendant's record. ${ }^{19}$ In contrast, discussions of the defendant's credibility during deliberations did not differ significantly between the two groups. ${ }^{20}$

Other researchers have also concluded that determinations of the defendant's credibility are not the prime method by which criminal record influences guilt judgments. For example, in Roselle Wissler and Michael Saks's mock juror study, jurors' ratings of the defendant's credibility did not differ across their control and record conditions. ${ }^{21}$ In addition, the researchers conducted an analysis of covariance that controlled for the potential mediating effect of credibility judgments, yet the significant impact of criminal record on mock juror verdicts remained. ${ }^{22}$ In a study by Edith Greene and Mary Dodge, $17 \%$ of mock jurors convicted the accused based on just the facts, compared to $40 \%$ of mock jurors who additionally learned of the defendant's prior record. ${ }^{23}$ Jurors who heard of the criminal record made more negative inferences about the defendant. Mock jurors' knowledge of the prior record affected their ratings of both the perceived dangerousness and the credibility of the defendant, in contrast to some other studies. There was no statistically significant difference between record and no-record jurors' reported threshold for conviction, that is, the minimum percentage of evidence that they would need to convict the defendant. ${ }^{24}$

Finally, Sally Lloyd-Bostock's British study varied the presence, similarity, and recency of prior convictions and found that mock jurors who learned of a recent similar conviction rated the probability that the defendant committed the crime as higher. ${ }^{25}$ These mock jurors estimated the probability of guilt as $66 \%$, compared to $52 \%$ for those who did not hear of a record. Similar and dissimilar convictions had different effects. Jurors who heard about a five-year-old conviction for a similar offense rated the defendant's tendency to commit this kind of crime as higher compared to the control condition. Credibility judgments did not differ between jurors who learned of similar records and jurors in the control condition; however, jurors who learned of a recent dissimilar record said that they were more likely to believe the defendant than jurors in any of the other conditions. ${ }^{26}$

19 Id. at 244-47.

$20 \quad I d$. at 247.

21 Wissler \& Saks, supra note 17, at 41-42 (finding that credibility ratings did not differ across conditions and that even after controlling for the impact of credibility judgments, prior records had strong effects on verdicts).

22 Id. at 42.

23 Greene \& Dodge, supra note 17 , at 72-74.

$24 \quad I d$. at 75.

25 Lloyd-Bostock, supra note 17, at 743-44.

26 Id. at 746-47. 
The different patterns for similar and dissimilar prior convictions led Lloyd-Bostock to conclude that jurors primarily used criminal-record evidence to infer propensity rather than to assess credibility. Further analyses showed that a previous conviction for indecent assault on a child created substantial prejudice above and beyond similarity to the currently charged offense, thus underscoring the point that the nature of a prior record may lead jurors to make inferences about the character of the defendant as well as the defendant's likelihood of having committed the offense. ${ }^{27}$ Interestingly, $66 \%$ of the mock jurors in the control condition, who were given no information about the defendant's record, said that they thought that he had at least one or more prior convictions. ${ }^{28}$

Thus, prior work indicates that jurors use similar criminal-record information to develop propensity judgments and other generally negative evaluations of a defendant. The evidence against a defendant with a prior record appears stronger to the jury. From the limited experimental study of the threshold hypothesis, the threshold for conviction does not seem to change. Although the defendant's credibility can be harmed by knowledge of a record, credibility does not appear to be the main way that criminal record information affects the guilt judgments of jurors. The experimental research also suggests that limiting instructions are not a reliable method for eliminating the negative impact of criminal records. ${ }^{29}$

\section{B. Research with Judges}

How criminal-record information might affect judicial decision making is also of interest, and a handful of studies examine this topic. The studies show similar negative effects caused by knowledge of a defendant's criminal record. For instance, one study presented American judges with a scenario of a products liability lawsuit in which the defendant company conceded liability but disputed the plaintiff's damages; the judge's task was to determine an appropriate damage award for the plaintiff's pain and suffering. ${ }^{30}$ Some judges also had to rule on the company's motion to introduce the plaintiff's fourteenyear-old fraud conviction, while other judges never heard of the plaintiff's record. The criminal record information led to marginal differ-

$27 \quad I d$. at $748-52$.

$28 \quad I d$. at 753.

29 For an excellent review of the literature, see Joel D. Lieberman \& Jamie Arndt, Understanding the Limits of Limiting Instructions: Social Psychological Explanations for the Failures of Instructions to Disregard Pretrial Publicity and Other Inadmissible Evidence, 6 Psychol. Pub. POL'y \& L. 677 (2000).

30 Andrew J. Wistrich, Chris Guthrie \& Jeffrey J. Rachlinski, Can Judges Ignore Inadmissible Information? The Difficulty of Deliberately Disregarding, 153 U. PA. L. REv. 1251, 1306-08 (2005). 
ences in award amounts. The authors point out that the precise mechanism by which the criminal record (even if it was suppressed, as most judges ruled) influenced judges is unknown. For instance, because the past crime was fraud, the judges might have drawn a negative inference about the credibility of testimony in the products liability case. Or, they may have judged the plaintiff to be an undesirable person and reduced his compensation. ${ }^{31}$

Lloyd-Bostock replicated part of her jury study with British lay magistrates. ${ }^{32}$ The magistrates watched the video depiction of the trial, completed initial individual questionnaires, and deliberated (as they do normally) in groups of three to arrive at group verdicts. ${ }^{33}$ Compared to a defendant with no record, when magistrates evaluated the same case of a defendant with a record, they rated the defendant's guilt as significantly higher. Like the majority of the mock jurors, $69 \%$ of the magistrates who learned nothing about a defendant's criminal record nonetheless judged him likely to have one. ${ }^{34}$

Another study had 88 Ohio judges and 104 jurors participate in parallel experiments testing the effect of limiting instructions and inadmissible evidence. ${ }^{35}$ Some of the judges and jurors were provided with facts that could not legally be considered in deciding the case, while others, in a control condition, did not hear the objectionable facts. Half of the judges and jurors who heard the inadmissible evidence received a limiting instruction directing that the evidence should be set aside, but the others did not receive this instruction. Both judges and jurors responded similarly. Those who heard the inadmissible evidence-even if told to disregard the information-responded more negatively, compared to judges and jurors in the control condition. ${ }^{36}$

One other study deserves mention. Peter Blanck videotaped judges' final legal instructions in jury trials. ${ }^{37}$ In a number of analyses of the videotapes, evaluators found that the extent of the defendants' criminal records was correlated with distinctive nonverbal behavior by judges during the final jury instructions. ${ }^{38}$ The impact on the jury

31 Id. at 1308.

32 See Sally Lloyd-Bostock, The Effects on Lay Magistrates of Hearing That the Defendant Is of "Good Character", Being Left to Speculate, or Hearing That He Has a Previous Conviction, 2006 Crim. L. Rev. 189.

$33 \quad I d$. at 194.

34 Id. at 194-95.

35 Stephan Landsman \& Richard F. Rakos, A Preliminary Inquiry into the Effect of Potentially Biasing Information on Judges and Jurors in Civil Litigation, 12 BEHAV. SCI. \& L. 113, 120 (1994).

$36 \quad I d$. at $122-25$.

37 Peter David Blanck et al., The Appearance of Justice: Judges'Verbal and Nonverbal Behavior in Criminal Jury Trials, 38 STAN. L. Rev. 89 (1985).

$38 \quad I d$. at $122-23$. 
decisions was not clear from this small study, but Blanck argues that judges' views may influence juries through both verbal and nonverbal channels. ${ }^{39}$

Although there are few judge studies, they tend to converge with the jury experiments and show similar patterns of more negative assessments and the difficulty of following limiting instructions regarding the use of a criminal record.

\section{Prior Research with Real Juries}

Complementing the experimental research are a few previous studies of real juries and the role of criminal records. In Harry Kalven and Hans Zeisel's 1950s classic national study of judicial agreement with jury verdicts in criminal trials, the presence of a criminal record appeared to be a prime determinant of a defendant's decision to testify at trial. ${ }^{40}$ When defendants had no prior record, they testified in $91 \%$ of cases; by comparison, defendants who had criminal records testified in $74 \%$ of cases. ${ }^{41}$ In their sample of criminal trials, $53 \%$ of defendants had criminal records while $47 \%$ did not. ${ }^{42}$ Interestingly, the link between taking the stand and the jury's learning of a defendant's record was not invariant. If a defendant with a record took the stand, $72 \%$ of the time the jury learned about the record; conversely, if a defendant with a record elected not to testify, $13 \%$ of the time the jury learned of the record anyway. ${ }^{43}$ Kalven and Zeisel attributed some disagreement between judge and jury over the verdict to whether defendants had criminal records and whether they took the stand. ${ }^{44}$ Kalven and Zeisel examined a set of cases in which the evidence was closely balanced. In this set of cases, for defendants with no records who took the stand, juries were more apt to acquit when judges would have convicted, compared to cases with defendants with records who did not take the stand. ${ }^{45}$ But note that this analysis conflates having a criminal record and taking the stand. ${ }^{46}$

\footnotetext{
39 Id. at 133.

40 Harry Kalven, Jr. \& Hans Zeisel, The American Jury 143-48 (1966).

41 Id. at 146 tbl.43 (basing percentages on 1143 cases from Sample II).

$42 I d$. at 145 tbl.42 (basing percentages on 1143 cases in Sample II); id. at 145 n.12 (basing percentages on 2385 cases from Sample I).

43 Id. at 147 tbl.44 (basing percentages on 1534 defendants from Samples I and II who had criminal records).

$44 \quad I d$. at 179 tbl.56.

45 Id.

46 Kalven and Zeisel did not conduct statistical analyses of these data; rather, they presented the data in tabular form. See generally id. Recently, Joseph Gastwirth and Michael Sinclair used statistical techniques to analyze Kalven and Zeisel's data on the impact of criminal record on judge-jury disagreement in criminal cases. Joseph L. Gastwirth \& Michael D. Sinclair, A Re-Examination of the 1966 Kalven-Zeisel Study of Judge-Jury Agreements and Disagreements and Their Causes, 3 L. Probability \& Risk 169 (2004). They found that in cases with closely balanced evidence, judge-jury disagreement was related to the
} 
In a study using 201 actual Indiana jury trials, Martha Myers reported a statistically significant association between the number of a defendant's prior convictions and the likelihood of conviction. Juries were more likely to convict defendants who had numerous prior convictions. But it appears that in just 36 of these jury trials, the defendant (or accomplices) provided statements or testimony about involvement or lack of involvement in the crime. ${ }^{47}$

Daniel Givelber published an interesting analysis of the NCSC data that are the subject of this Article. On the basis of his analysis, Givelber concluded that the jurors' knowledge of a defendant's criminal record made little difference in jury verdicts. ${ }^{48}$ That study did not account for the defendant's decision whether to testify. Givelber's analysis treated all cases in which the jury did not become aware of a defendant's criminal history the same, whether or not the defendant testified. The effect of defendants' testimony on their convictions should be assessed in conjunction with the decision to testify, as the decision to testify is not a random act. At a minimum, one should explore the effect of a criminal record in cases in which defendants testify because these are the cases in which the jury is most apt to learn about criminal records, if they exist.

Givelber and Amy Farrell, again using the NCSC data, explore the relation between the case the defense presented and the verdict. They include having a criminal record as an explanatory factor for verdict and report that juries are four times more likely to acquit if the defendant has no prior criminal record. ${ }^{49}$ Given their research question, their model includes cases in which the defendant had no criminal record, so they do not test the effect of the jury's learning about a criminal record conditional on the defendant having a criminal record. The relation between verdict and learning about a criminal record may be confounded in such a model by cases in which the defendant did not have a criminal record. Acquittals in such cases may be attributable to the absence of a criminal record or to the jury not learning about the record, given that one exists, as Givelber and Farrell note. ${ }^{50}$

presence of superior defense counsel, a sympathetic defendant, and the defendant's criminal record. $I d$. at 174 . In clear-evidence cases, a sympathetic defendant and the absence of a prior record helped the defendant's case. Id. at 183, 184 tbl.9.

47 Martha A. Myers, Rule Departures and Making Law: Juries and Their Verdicts, 13 LAw \& Soc'y REv. 781, 786-87 tbl.1, 793 tbl.2 (1979).

48 Daniel Givelber, Lost Innocence: Speculation and Data About the Acquitted, 42 AM. CRIM. L. REv. 1167, 1190 (2005).

49 Daniel Givelber \& Amy Farrell, Judges and Juries: The Defense Case and Differences in Acquittal Rates, 33 Law \& Soc. InQuiry 31, 45-47 (2008).

$50 \quad I d$. at 47 . Our results suggest that the effect of criminal record is in one sense stronger and in another sense weaker than Givelber and Farrell report. In low-evidentiarystrength cases, we find a statistically significant association between learning about criminal 


\section{Some Caveats}

Several factors might make it difficult to detect effects of criminal records on real juries, even if defendants' records influence case outcomes. First is the issue of selection bias. ${ }^{51}$ Some of the impact of criminal record may occur at early stages of case processing. Undoubtedly criminal record plays a role in who is initially investigated by police, who is targeted for prosecution, and who receives a favorable plea agreement prior to trial. Thus, in comparing cases in which defendants do or do not have past criminal records, one may reasonably assume that these defendants and their cases may differ in a variety of ways in addition to their criminal pasts.

Similarly, a defendant's criminal record may affect the decision to take the stand-a focus of this Article. The evidence and other factors in cases with and without defendant testimony are apt to differ in myriad ways because only cases with such testimony directly raise issues of credibility. Thus, it is challenging to separate the effects of the defendant's criminal record and the effects of the defendant's testimony.

Furthermore, the type of criminal record should influence the decision to testify and other behavior. For example, the prior crimes among defendants who testify are apt to be more minor, or at least less probative of guilt, than among defendants who do not take the stand. Judges may be especially concerned about the prejudicial effects of similar crime records. Yet prosecutors might try harder to get the prior conviction into evidence if the crime is especially probative. Because we lack information about the nature of defendants' prior crimes, we cannot control for the influence that the nature of the crime has on the decision to testify or on the jurors' decision to convict or acquit.

Setting aside selection effects, another factor limiting the ability to isolate the effect of a criminal record is conflating the criminal record with the perceived strength of evidence. As discussed above, jurors who learn that a defendant has a criminal record may

history and case outcome. In high-evidentiary-strength cases, we find no significant association between learning about criminal history and case outcome. See infra tbl.9. For Givelber and Farrell's concern about using the NCSC evidentiary-strength variables, see Givelber \& Farrell, supra note 49, at 39 n.6.

51 Cf. Kevin M. Clermont \& Theodore Eisenberg, Trial by Jury or Judge: Transcending Empiricism, 77 CORNELL L. REv. 1124 (1992) (exploring the potentially confounding impact of selection effects in comparing judge and jury trial outcomes). As Kevin Clermont and Theodore Eisenberg describe, because parties may choose a judge or a jury trial, cases heard by judges and juries may differ along multiple dimensions, making it difficult to attribute the cause of outcome differences to the fact finder alone. Likewise, because police and prosecutors may consider defendants' criminal records in deciding whether to investigate, arrest, and prosecute, the cases of defendants who do and do not have criminal records may differ along multiple dimensions. See id. at 1128-33. 
incorporate that information into their narrative account of the evidence in the case, seeing the case as having stronger evidence favoring conviction. The evidentiary-strength variables would contain most of the information embodied in the knowledge of criminal history variable. If one uses judgments of evidence strength to control for the closeness of the case, as we do here, a defendant's criminal history might not emerge as a statistically significant independent factor, even if it had an effect.

Notwithstanding these caveats, the data analyzed here have a special strength worth noting. Prior studies try to assess the overall strength of the evidence by indirect measures. Thus, to assess evidentiary strength, researchers have relied on the presence of classes of evidence such as eyewitness identification testimony, expert testimony, or physical evidence. ${ }^{52}$ But the existence of a class of evidence does not necessarily affect case outcomes. For example, a jury can view expert testimony as strongly implicating a defendant or as having little probative value. Proxies for evidentiary strength cannot capture the jurors' overall assessments of the quality of the case. As described below, this study contains a quantitative measure of the jurors' overall estimates of the strength of the evidence against the defendants. We thus have a reasonable control for evidentiary strength that allows us to test the contribution of criminal record to case outcome.

\section{II}

\section{Data Description}

The NCSC gathered the data used in this study as part of a NIJfunded project to study hung juries. The NCSC's report, Are Hung Juries a Problem?, ${ }^{53}$ thoroughly describes the data, so the description here, derived from the NCSC report, is more abbreviated. The data have also been used in several other studies. ${ }^{54}$

52 See, e.g., Myers, supra note 47, at 786 tbl.1.

53 See Paula L. Hannaford-Agor, Valerie P. Hans, Nicole L. Mott \& G. Thomas Munsterman, Are Hung Juries a Problem? 29-40 (2002), available at http://www.ncsconline.org/ WC/Publications/Res_Juries_HungJuriesProblemPub.pdf.

54 The description of research methodology in this Article is drawn from the study description in Theodore Eisenberg, Paula L. Hannaford-Agor, Valerie P. Hans, Nicole L. Waters, G. Thomas Munsterman, Stewart J. Schwab \& Martin T. Wells, Judge-Jury Agreement in Criminal Cases: A Partial Replication of Kalven and Zeisel's The American Jury, 2 J. EmPIRICal Legal Stud. 171 (2005). Other studies using these data include Stephen P. Garvey, Paula Hannaford-Agor, Valerie P. Hans, Nicole L. Mott, G. Thomas Munsterman \& Martin T. Wells, Juror First Votes in Criminal Trials, 1 J. EmPIRICAL Legal Stud. 371 (2004); Givelber, supra note 48; Givelber \& Farrell, supra note 49; Valerie P. Hans, Paula L. Hannaford-Agor, Nicole L. Mott \& G. Thomas Munsterman, The Hung Jury: The American Jury's Insights and Contemporary Understanding, 39 CRIM. L. Bull. 33 (2003); Michael Heise, Criminal Case Complexity: An Empirical Perspective, 1 J. Empirical Legal Stud. 331 (2004); Spencer, supra note 8. 
Four sites participated in the data collection: The Central Division, Criminal, of the Los Angeles County Superior Court, California; the Maricopa County Superior Court (Phoenix), Arizona; the Bronx County Supreme Court, New York; and the Superior Court of the District of Columbia. Several criteria shaped site selection. First, each site needed a sufficiently high volume of felony jury trials to permit data collection within a reasonable time period. Second, court personnel had to be willing to cooperate in data collection, including agreeing to adhere to privacy and confidentiality protocols. Los Angeles and Washington, D.C., were included because of reported concerns about hung jury rates. Maricopa was chosen to study the effects of an innovative procedure allowing judges to admit further evidence and arguments in cases with deadlocked juries. The New York State Office of Court Administration provided suggestions about high-volume courts in New York City and helped secure the Bronx County Supreme Court's cooperation.

After a pretest in Los Angeles, ${ }^{55}$ data were collected at the four sites. Data were collected in Los Angeles from June, 2000, through October, 2000. ${ }^{56}$ Maricopa County began data collection in November of 2000 and ended in October, 2001. ${ }^{57}$ Data from the Bronx were collected from February through August, 2001, and data for Washington, D.C. were collected from April through August, 2001.

Court personnel at the sites distributed and collected questionnaire packets covering noncapital felony cases in all site courtrooms. The sample excludes misdemeanor cases because hung juries in felony trials are typically of greater concern to policymakers. The sample excludes capital cases because of the sanction's severity and because of the risk that confidential juror questionnaire data might be used in litigation. Further information about the data collection is available in NCSC's report. ${ }^{58}$

The Questionnaires. Each packet contained instructions and questionnaires for the judges, attorneys, and jurors. Each packet also had a case data form requesting information about case characteristics and outcomes. Many of the questions asked trial participants to give ratings on a seven-point Likert scale. The content of each questionnaire

55 Hannaford-Agor, Hans, Mott \& Munsterman, supra note 53, at 29.

56 This period overlapped with a significant local investigation of the Los Angeles police (the Ramparts investigation), producing some concern about the typicality of the conviction/acquittal ratio. Id.

57 A brief hiatus during this period was the result of some confusion on which cases were to be included in the study. For a short time, some judges believed that data were to be collected only if the jury hung. Thus, the number of hung juries in Maricopa County may be elevated. Id. The hung jury rates in Maricopa were 3.3\% (hung on all counts), $5.1 \%$ (hung on count one), and $7.7 \%$ (hung on any count). Id. at 41 tbl.4.1.

58 See id. at 29-31. 
most relevant to this study is listed below and is described more fully in the NCSC report. ${ }^{59}$

- Case Data Form-type of charge, sentence range, jury's decision, and demographic information about the defendant(s) and the victim(s), voir dire, trial evidence and procedures, and jury deliberations. This form included a specific question about whether the defendant had a criminal record and whether the jury learned of that record.

- Judge Questionnaire—(Part I—before jury verdict) verdict judge would have reached in bench trial, evaluation of the evidence, case complexity, attorney skill, and likelihood that the jury would hang; (Part II-after jury verdict) reaction to the verdict and experience on the bench.

-Juror Questionnaire-case complexity, attorney skill, evaluation of the evidence, rating of the believability of the defendant as a witness, rating of sympathy for the defendant, formation of opinion, dynamics of the deliberations including the first and final votes, juror participation, conflict, reaction to verdict, opinion about applicable law, assessment of criminal justice in the community, and demographic information.

Distribution of Study Packages. Researchers briefed judges and key court personnel about the project and instructed them about how the packet distribution was to occur. ${ }^{60}$ Packets were sent from the jury assembly room to the courtrooms with the panel for voir dire. Once the jury was selected, court personnel distributed the packets to the judge and/or court clerk. If the case proceeded through to jury deliberations and did not end by a plea agreement, dismissal, or mistrial for some reason other than the jury's inability to arrive at a unanimous verdict, the judge was asked to complete the judge survey. In addition, either the clerk or the judge was to complete a questionnaire about general case information on a case data form.

Once the jury retired to deliberate, court personnel distributed the questionnaire to the judges. The judges were asked to complete the questionnaires in two stages, answering some questions prior to the jury decision (Part I) and the remaining questions after the jury rendered its verdict or the case was declared a mistrial (Part II). The court personnel distributed the final set of questionnaires to the jurors after the verdict was announced or a mistrial declared. To protect confidentiality, respondents were provided blank envelopes for completed questionnaires. Court staff collected the completed ques-

$59 I d$. at 30 app. A. The contents of the Attorney Questionnaire are not included here because the current analysis does not include items from attorneys.

60 For the time sequence of the packet distribution, see $i d$. at 31 fig.3.1. 
tionnaires and gave these to the designated court liaison for each site, who forwarded the cases to the NCSC for data entry and analysis.

Response Rates. The NCSC report summarizes response rates. ${ }^{61}$ Briefly, case data forms were returned in 358 of the 401 cases, an $89 \%$ response rate. Judges completed 366 questionnaires (91\% response rate). Although confidentiality precludes us from linking the data in a particular case to an individual judge, we are confident that a substantial number of judges are represented in the sample. For example, in Maricopa County, twenty-nine judges sat in the criminal division in fiscal year 2000-2001.62

Overall, 3626 jurors returned their questionnaires. The response rate for jurors across all sites, with consideration for jury size, was $80 \%$. For the twelve-person juries in Los Angeles, Maricopa, the Bronx, and D.C., the average response rate was eleven, ten, eight, and ten jurors, respectively. ${ }^{63}$ For the eight-person juries in Maricopa, ${ }^{64}$ an average of seven jurors responded. The Case Data Form surveys asked factual information about the criminal charges filed and the jury's decision ${ }^{65}$ and led to 382 usable cases, though particular analyses reported below have fewer observations due to data missing on variables under consideration. The number of questionnaires included in the final usable database varied slightly for each site and is summarized in the NCSC report. ${ }^{66}$

III

Defendant Testimony and Juries' Learning of CRIMINAL RECORD

Preliminarily, the judges' descriptions of the importance of defendant testimony confirm that defendant testimony plays a promi-

61 See id. at 32-33.

62 E-mail from Judge G.T. Anagnost to Theodore Eisenberg (Jan. 26, 2004) (on file with author). For a race and gender breakdown of the judges, see Eisenberg, HannafordAgor, Hans, Waters, Munsterman, Schwab \& Wells, supra note 54, at 205 n.61.

63 In California, New York, and D.C., twelve-person juries try felony cases. See CAL. Const. art. I, § 16; N.Y. Const. art. VI, § 18; D.C. CodE $§ 16-705$ (2006).

64 Arizona law provides for eight-person juries in felony trials unless the penalty for the defendant includes death or a potential sentence of thirty years or more, in which case there are twelve jurors. See ArIz. Const. art. II, § 23. In Maricopa County, there were thirty cases with twelve-member juries and sixty-nine juries with eight members. Six cases had too little information to determine jury size. Hannaford-Agor, Hans, Mott \& Munsterman, supra note 53, at 30 .

65 If this key information was missing from the questionnaires, NCSC made follow-up inquiries with the courts. NCSC salvaged thirty-one cases without Case Data Forms through direct communication with the courts to obtain the key information about the cases. The courts were unable to recover this missing information in twelve cases, which were not included in the final data analysis. Seven additional cases had so little information (three or fewer questionnaires received) that they were also eliminated from the analysis. Id.

66 Id. at 33 tbl.3.1. 
nent role at trial. ${ }^{67}$ In the cases in which defendants testified, judges reported that, on average, defendant testimony was more important than that of the police, of informants, of co-defendants, and of expert witnesses. Only victim testimony received a higher mean score on the Likert one-to-seven scale, and even this difference was only marginally statistically significant $(p=0.075$, Wilcoxon matched pairs signed-rank test). Judges viewed defendant testimony as significantly more important than police testimony $(\mathrm{p}<0.001)$, informant testimony $(\mathrm{p}<0.001)$, codefendant testimony $(\mathrm{p}=0.003)$, and expert-witness testimony $(\mathrm{p}<0.001)$. Defendant testimony was not significantly more important than eyewitness testimony $(p=0.597)$.

Defendants' testifying presumably directly affects whether jurors learn of a defendant's prior criminal record, if any. So we first determine whether defendants testified and then assess whether such testimony is associated with juries' learning about past convictions. We explore in Parts III.A and III.B the relation between individual factors and the decision to testify and juries' learning about criminal history. Part III.C assesses these factors in regression models.

\section{A. Defendant Testimony: Case Characteristics Considered Separately}

Because defendant testimony is important, it is reasonable to explore the factors that might be expected to influence a defendant's decision to testify. Given the threat of impeachment with a prior conviction, the most obvious hypothesis is that defendants are more reluctant to testify if they have a prior criminal record than if they do not. One way or another, they may worry, the prosecution will be able to use the record in cross-examination, thereby disadvantaging the defendant.

However, in addition to whether the defendant has a prior criminal record, other factors such as evidentiary strength, race, sex, and type of crime should also be considered. In the fairly unusual case when defense counsel believes conviction is highly unlikely even without a defendant denial, the risk of testifying may not be worth the possible benefit. So the overall perceived strength of the evidence might be associated with the decision to testify.

Additionally, personal background variables, especially race and sex, might be associated with the decision to testify. At the aggregate level, minorities and whites have different perceptions about the criminal justice system, ${ }^{68}$ and these perceptions might lead to different rates of testifying. Men and women might react differently to the

67 See id. at 50, 51 tbl.4.7.

68 See, e.g., Theodore Eisenberg, Stephen P. Garvey \& Martin T. Wells, Forecasting Life and Death: Juror Race, Religion, and Attitude Toward the Death Penalty, 30 J. Legal Stud. 277, 
prospect of a public appearance on the witness stand or to other influences. Perception of the defendant's general appeal as a witness will influence the decision to testify, as it would for any other witness.

The nature of the crime charged could also be relevant. The trial judge must weigh the potential prejudice to the defendant of a prior conviction coming into evidence. That balancing process may differ depending on the type of crime at trial.

Table 1 shows the relation between the first four factors and whether the defendant testified at trial.

Table 1. Defendant Testimony and Selected Characteristics

\begin{tabular}{|c|c|c|c|}
\hline \multicolumn{2}{|c|}{ Panel A. Defendant Characteristic, Dichotomous variables } \\
\hline & Number not testifying & Number testifying & $\%$ testifying \\
\hline Defendant: had prior record & 137 & 114 & 45.4 \\
\hline had no prior record & 30 & 49 & $62.0^{*}$ \\
\hline Defendant: was minority & 145 & 130 & 47.3 \\
\hline was white & 12 & 21 & $63.6 \dagger$ \\
\hline Defendant: was male & 147 & 138 & 48.4 \\
\hline was female & 9 & 20 & $69.0 *$ \\
\hline PANel B. Case Characteristic, continuous variables & & \\
\hline \multicolumn{2}{|c|}{ testifying } & $\begin{array}{c}\text { Mean of those } \\
\text { testifying }\end{array}$ \\
\hline Evidence strength-judges' view & 4.88 & 4.72 & $51.5(\mathrm{~N}=346)$ \\
\hline Evidence strength-jurors' view & 4.62 & 4.38 & $49.8(\mathrm{~N}=3142)$ \\
\hline
\end{tabular}

Note: NCSC data covering trials at four sites in 2000-2001; 163 of 330 defendants (49.4\%) testified. The third numerical column reports the significance level of difference between those with and without a characteristic. For significance levels, $\dagger$ indicates $p<0.10$, * indicates $\mathrm{p}<$ 0.05 . Significance levels at the case level account for stratification of sample by site. Significance levels at the juror level ("Evidence strength-jurors' view") account for both site stratification and the non-independence of observations at the case level. The minority-white comparison treats blacks and Hispanics as minorities and excludes two Asians and fifteen defendants classified as being of "other" races. Strength of evidence in Panel B is coded on a one-to-seven Likert scale, with higher values indicating evidence more favorable to the prosecution.

Panel A first shows the association between the existence of a prior criminal record and whether the defendant testified at trial. In 251 of 330 cases with information available about prior records and whether the defendant testified, the defendants had criminal records. Forty-five percent of defendants with prior records testified, compared to $62 \%$ of defendants without known prior records. The difference in the proportion of defendants with and without criminal records who testify is statistically significant $(\mathrm{p}=0.011)$.

284-85 nn.33, 35-36 (2001) (citing sources about racial differences in attitude toward the death penalty); $i d$. at 298 n.80 (citing sources about juror race and decision making). 
Panel A also shows that minorities, used here to include blacks and Hispanics, comprise the bulk of defendants in the studied sites. ${ }^{69}$ The four sites studied all have substantial minority populations. Only 33 cases involved white defendants, compared to 275 with minority defendants. Although over $60 \%$ of white defendants testified, less than half of minority defendants testified. This result is marginally statistically significant.

This result, however, could be the product of confounding due to races having different rates of prior criminal records. Minority defendants were more likely to have criminal histories than white defendants were. Of 275 minority defendants, 215 (71.2\%) had prior records. Of 33 white defendants, $18(54.6 \%)$ had criminal records. This difference is statistically significant at $p=0.005$. Table 2 , therefore, shows the percentage of defendants who testified, controlling for minority status and prior criminal record. Two-thirds of white defendants without prior criminal records testified, compared to a slightly lower $62 \%$ of minority defendants. The big difference in rate of testimony is between whites who had criminal records and minorities who had criminal records. About 6 in 10 whites with criminal records testified, compared to about 4 in 10 minorities with criminal records.

Panel A of Table 1 also shows gender differences in the relation between having a prior record and testifying. About $48 \%$ of males testified, compared to $69 \%$ of females. This difference is statistically significant $(p=0.036)$ despite the few women defendants. Panel B of Table 1 indicates that there are no significant differences in the strength of evidence between cases of defendants who did or did not testify. This is so whether one uses the judge's or the jury's view of evidentiary strength.

Table 3 reports the relation among the type of criminal case, the existence of a prior record, and the decision to testify. It shows substantial variation in the rate of testimony by type of case, both for defendants with and without criminal records. For defendants without criminal records, the rate of testifying ranged from over $93 \%$ in assault cases to just over $14 \%$ in second-degree murder cases. For defendants with criminal records, testifying rates ranged from $14 \%$ in attempted murder cases to about $57 \%$ in assault cases to over $70 \%$ in the residual category of "Other" case types. In addition, rates varied within case type depending on whether the defendant had a prior record. For the largest case type in which defendants did not have criminal records, assault, the $93 \%$ testimony rate for defendants without criminal records is accompanied by a $57 \%$ rate for defendants

69 The analysis excludes two cases with Asian defendants and fifteen cases with defendant race designated as "other." Cases with insufficient information about race are likewise excluded. 
Table 2. Race, Prior Record, and Rates of Testifying

\begin{tabular}{|c|c|c|c|}
\hline & $\begin{array}{c}\text { Defendant had } \\
\text { no prior record }\end{array}$ & $\begin{array}{c}\text { Defendant had } \\
\text { prior record }\end{array}$ & Total \\
\hline White DEFENDANT & & & \\
\hline Testimony rate (\%) & 66.7 & 61.1 & 63.6 \\
\hline Number of cases & 15 & 18 & 33 \\
\hline MinORITY DEFENDANT & & & \\
\hline Testimony rate (\%) & 61.7 & 43.3 & 47.3 \\
\hline Number of cases & 60 & 215 & 275 \\
\hline TotaL & & & 49.0 \\
\hline Testimony rate (\%) & 62.7 & 233 & 308 \\
\hline Number of cases & 75 & & \\
\hline
\end{tabular}

Note: NCSC data covering trials at four sites in 2000-2001.

with criminal records $(p=0.024$, Fisher's exact test $)$. A similar large difference exists for first-degree murder cases $(p=0.056$, Fisher's exact test).

\section{B. Juries' Learning About Prior Criminal Records: Case Characteristics Considered Separately}

Testifying is risky for defendants with prior criminal records because the records may be revealed on cross-examination. To assess whether juries learn of criminal records, we limit the sample to those cases in which the defendant had a prior record. Using this reduced sample, Table 4 shows the relation among defendant characteristics, evidentiary strength, and whether the jury learned about the defendant's criminal record.

Panel A first shows the association between whether the defendant testified and the jury's learning of the prior record. Note that by far the most frequent pattern, accounting for about half the cases, was for the defendant not to testify and for the jury not to learn about the prior record. Interesting variation nevertheless emerges. Panel A shows a statistically significant association $(p<0.001)$ between defendants' testifying and juries' learning about the records. About $52 \%$ of juries learned of a defendant's record if the defendant testified. In contrast, juries learned about criminal record if defendants did not testify in less than $9 \%$ of cases, a low rate, similar to that reported by Kalven and Zeisel. ${ }^{70}$ Because only about half the juries with testifying defendants learned of criminal records, the results suggest that judges, as evidentiary rules require, balance the relevance of a prior criminal record with the possible prejudice to the defendant.

70 See KAlven \& Zeisel, supra note 40, at 147 (reporting that juries learn of records in $13 \%$ of the cases in which defendants do not testify). 
Table 3. Percent of Cases in Which Defendant Testified, by Case Type and Existence of Prior Record

\begin{tabular}{|l|c|c|c|}
\hline Case type & No prior record & Prior record & Total \\
\hline Assault (not sexual) & 15 & 21 & 36 \\
\hline & $(93.3)$ & $(57.1)$ & $(72.2)$ \\
\hline Attempted murder & 4 & 7 & 11 \\
\hline & $(25.0)$ & $(14.3)$ & $(18.2)$ \\
\hline Burglary & 4 & 10 & 14 \\
\hline & $(50.0)$ & $(60.0)$ & $(57.1)$ \\
\hline DUI/DWI & 5 & 7 & 12 \\
\hline & $(40.0)$ & $(42.9)$ & $(41.7)$ \\
\hline Illegal drug possession & 2 & 24 & 26 \\
\hline & $(50.0)$ & $(50.0)$ & $(50.0)$ \\
\hline Illegal drug sale & 20 & 46 & 66 \\
\hline & $(50.0)$ & $(45.7)$ & $(47.0)$ \\
\hline Larceny/theft & 5 & 11 & 16 \\
\hline & $(40.0)$ & $(45.5)$ & $(43.8)$ \\
\hline Murder, first-degree & 6 & 23 & 29 \\
\hline & $(66.7)$ & $(21.7)$ & $(31.0)$ \\
\hline Murder, second-degree & 7 & 6 & 13 \\
\hline & $(14.3)$ & $(16.7)$ & $(15.4)$ \\
\hline Rape, other sex crimes & 11 & 7 & 18 \\
\hline & $(63.6)$ & $(57.1)$ & $(61.1)$ \\
\hline Robbery & 5 & 38 & 43 \\
\hline & $(40.0)$ & $(44.7)$ & $(44.2)$ \\
\hline Weapons & 6 & 13 & 19 \\
\hline & $(66.7)$ & $(38.5)$ & $(47.4)$ \\
\hline Other & 5 & $(45.5)$ & 15 \\
\hline & $(50.0)$ & $68.0)$ \\
\hline Total & & 328 \\
\hline & $55.8)$ & $48.5)$ \\
\hline
\end{tabular}

Note: NCSC data covering trials at four sites in 2000-2001. Cells show counts with percents of cases with the relevant characteristic in which defendant testified in parentheses.

Juries in minority defendants' cases were more likely to learn of criminal histories than were juries in white defendants' cases. Of 226 minority defendants with criminal records, sixty-six (29.2\%) had juries who learned of their criminal records. Of nineteen white defendants with criminal records, three $(15.8 \%)$ had juries who learned of their records. But this difference does not reach traditional levels of statistical significance $(p=0.291)$, and more observations, especially of white defendants, are needed to support conclusions.

Panel A also suggests gender differences in the rate at which juries learned of criminal records. Juries learned of criminal records for 
Table 4. Defendant Testimony and Jury Knowledge of
Criminal Record

\begin{tabular}{|c|c|c|c|}
\hline & $\begin{array}{l}\text { Jury did not learn of } \\
\text { criminal record }(\mathrm{N})\end{array}$ & $\begin{array}{l}\text { Jury learned of } \\
\text { criminal record }(\mathrm{N})\end{array}$ & $\begin{array}{l}\% \text { learning of } \\
\text { criminal record }\end{array}$ \\
\hline Defendant: testified & 55 & 59 & 51.8 \\
\hline did not testify & 125 & 12 & $8.8^{* * * *}$ \\
\hline Defendant: was minority & 160 & 66 & 29.2 \\
\hline was white & 16 & 3 & 15.8 \\
\hline Defendant: was male & 162 & 71 & 30.5 \\
\hline was female & 16 & 2 & $11.1 \dagger$ \\
\hline \multicolumn{4}{|c|}{ Panel B. Case Characteristic, continuous variables } \\
\hline & $\begin{array}{l}\text { Mean of cases, jury } \\
\text { did not learn of } \\
\text { criminal record }\end{array}$ & $\begin{array}{c}\text { Mean of cases, jury } \\
\text { did learn of } \\
\text { criminal record } \\
\end{array}$ & \\
\hline $\begin{array}{l}\text { Evidence strength- } \\
\text { judges' view }\end{array}$ & 4.94 & 4.76 & $28.9(\mathrm{~N}=235)$ \\
\hline $\begin{array}{l}\text { Evidence strength-jurors' } \\
\text { view }\end{array}$ & 4.75 & 4.53 & $28.1 \quad(\mathrm{~N}=2299)$ \\
\hline
\end{tabular}

Note: NCSC data covering trials at four sites in 2000-2001. Cells show counts. Sample is limited to cases in which defendant had a prior criminal record. For significance levels, $\dagger$ indicates $\mathrm{p}$ $<0.10$; $* * *$ indicates $\mathrm{p}<0.001$. Significance levels at the case level account for stratification of sample by site. Significance levels at the juror level account for both site stratification and the non-independence of observations at the case level. The minority-white comparison treats blacks and Hispanics as minorities and excludes two Asians and fifteen defendants classified as being of "other" races. Strength of evidence in Panel B is coded on a one-to-seven Likert scale, with higher values indicating evidence more favorable to the prosecution.

about $30 \%$ of male defendants, compared to $11 \%$ for female defendants. This difference is marginally significant at $\mathrm{p}=0.107$, with the low number of female defendants this time being an issue.

Differences in juries' learning about criminal records are not significantly associated with the overall strength of the case. This is so whether one uses the judges' or the juries' views of evidentiary strength.

Table 5 reports the relation between the type of criminal case and whether the jury learned of a criminal record. The sample is again limited to cases in which the defendant had a criminal record. Although the overall significance of the table is merely $p=0.121$ and the numbers are small for most case types, the most striking result is that jurors learned of criminal records in $71 \%$ (five of seven) rape-sexual battery cases. Only one other case type, burglary, had even a $50 \%$ rate.

The noticeably higher rate in sex cases likely is due at least in part to special evidentiary rules applicable to such cases. California's general prohibition on admissibility of character evidence ${ }^{71}$ does not ap-

71 See Cal. Evid. Code $\$ 1101$ (a) (West 2007). 
Table 5. Jury Learning of a Defendant's Criminal Record BY TYPE OF CASE

\begin{tabular}{|c|c|c|c|}
\hline & $\begin{array}{l}\text { Jury did not learn of } \\
\text { criminal record }\end{array}$ & $\begin{array}{l}\text { Jury learned of } \\
\text { criminal record }\end{array}$ & Total \\
\hline \multicolumn{4}{|l|}{ Case type } \\
\hline \multirow[t]{2}{*}{ Assault (not sexual) } & 16 & 6 & 22 \\
\hline & $(72.7)$ & $(27.3)$ & $(100)$ \\
\hline \multirow[t]{2}{*}{ Attempted murder } & 7 & 1 & 8 \\
\hline & $(87.5)$ & $(12.5)$ & $(100)$ \\
\hline \multirow[t]{2}{*}{ Burglary } & 5 & 6 & 11 \\
\hline & $(45.5)$ & $(54.6)$ & 100 \\
\hline \multirow[t]{2}{*}{ DUI/DWI } & 7 & 0 & 7 \\
\hline & $(100.0)$ & $(0.0)$ & $(100)$ \\
\hline \multirow[t]{2}{*}{ Illegal drug possession } & 17 & 7 & 24 \\
\hline & $(70.8)$ & $(29.2)$ & $(100)$ \\
\hline \multirow[t]{2}{*}{ Illegal drug sale } & 33 & 16 & 49 \\
\hline & $(67.4)$ & $(32.7)$ & $(100)$ \\
\hline \multirow[t]{2}{*}{ Larceny/theft } & 7 & 4 & 11 \\
\hline & $(63.6)$ & $(36.4)$ & $(100)$ \\
\hline \multirow[t]{2}{*}{ Murder, first-degree } & 22 & 3 & 25 \\
\hline & $(88.0)$ & $(12.0)$ & $(100)$ \\
\hline \multirow[t]{2}{*}{ Murder, second-degree } & 6 & 3 & 9 \\
\hline & $(66.7)$ & $(33.3)$ & $(100)$ \\
\hline \multirow[t]{2}{*}{ Rape, other sex crimes } & 2 & 5 & 7 \\
\hline & $(28.6)$ & $(71.4)$ & $(100)$ \\
\hline \multirow[t]{2}{*}{ Robbery } & 26 & 12 & 38 \\
\hline & $(68.4)$ & $(31.6)$ & $(100)$ \\
\hline \multirow[t]{2}{*}{ Weapons } & 10 & 3 & 13 \\
\hline & $(76.9)$ & $(23.1)$ & $(100)$ \\
\hline \multirow[t]{2}{*}{ Other } & 15 & 5 & 20 \\
\hline & $(75.0)$ & $(25.0)$ & $(100)$ \\
\hline \multirow[t]{2}{*}{ Total } & 173 & 71 & 244 \\
\hline & $(70.9)$ & $(29.1)$ & $(100)$ \\
\hline
\end{tabular}

Note: NCSC data covering trials at four sites in 2000-2001. Cases limited to defendants with criminal records. Cells show counts with percents of cases with the relevant characteristic in which jury learned or did not learn of criminal record in parentheses.

ply to the admissibility of prior sexual crimes in cases involving sexual offenses. ${ }^{72}$ Arizona loosens restrictions on character evidence in sexual misconduct cases. ${ }^{73}$ The District of Columbia follows a rule that "allows proof of a defendant's past sexual misconduct, similar to the sexual misconduct for which he is being tried, in order to show that

73 See Ariz. R. Evid. 404(c). 
he has an "unusual sexual preference." 74 Similar legislation has been proposed in the New York State Assembly, ${ }^{75}$ but the absence of special prior-sexual-offense legislation does not necessarily preclude impeachment of New York defendants with prior sexual offenses. ${ }^{76}$

\section{Modeling Influences on the Decision to Testify and Juries' Learning About Prior Criminal Records}

With respect to defendants' testifying, considering variables in isolation from one another, we find that the existence of a prior criminal record, case type, race, and gender are associated with the decision to testify. This section combines these factors in models of the decision to testify. With respect to juries' learning of a defendant's criminal record, defendants' testifying is the strongest influence, but the other factors considered have notable, albeit not statistically significant, differences. This section considers the factors explored simultaneously in regression models.

Table 6 reports regression models of the decision to testify that combine the factors explored in subpart A. Model (1) does not account for type of case. Model (2) uses dummy variables to account for type of case. A test of the hypothesis that the coefficients for these variables are collectively equal to zero yields $p=0.148$, though some case types are individually significant. Both models account for the sample stratification by site. ${ }^{77}$ Of the factors explored in modeling the decision to testify-the existence of a prior criminal record, race, sex, strength of the evidence, and case type-only prior record and case type (not shown separately) are statistically significantly associated, or marginally significantly associated, with the decision to testify. The models explain the data substantially better than a simple model of testifying that would be correct in $51 \%$ of the cases based on the simple frequencies in Table 2. Similar models, using site fixed effects, do not materially differ from those reported here.

It is possible that a defendant's testifying is associated with the overall closeness of the case and that the closeness of the case is simultaneously associated with whether a defendant testified. Defense

74 Johnson v. United States, 610 A.2d 729, 730 (D.C. 1992) (quoting Pounds v. United States, 529 A.2d 791, 793-94 (D.C. 1987)).

75 See 2007 N.Y. Assem. Bill 6744, 230th Gen. Assem., Reg. Sess., §§ 16, 17 (N.Y. 2007).

76 See People v. Williams, 806 N.Y.S.2d 266, 268 (N.Y. App. Div. 2005) (allowing crossexamination in a rape case regarding the existence and underlying facts of prior sex-related convictions); see also FED. R. EvID. 413(a) (stating that evidence of other sexual assault offenses "may be considered for its bearing on any matter to which it is relevant").

77 We have also explored, but do not report, multilevel models, see, for example, Andrew Gelman \& Jennifer Hill, Data Analysis Using Regression and Multilevel/Hierarchical Models 301-21 (2007), to account for locale and type of case. The results do not materially differ from those reported here. 
Table 6. Logistic Regression Models of Decision to Testify

\begin{tabular}{|c|c|c|}
\hline & $(1)$ & $(2)$ \\
\hline & \multicolumn{2}{|c|}{$\begin{array}{l}\text { Dependent variable }=\text { defendant testified } \\
(0=\text { no, } 1=\text { yes })\end{array}$} \\
\hline \multirow[t]{2}{*}{ Defendant had prior record } & $-0.541 \dagger$ & $-0.663^{*}$ \\
\hline & $(1.89)$ & $(2.02)$ \\
\hline Minority defendant & $\begin{array}{c}-0.474 \\
(1.17)\end{array}$ & $\begin{array}{c}-0.478 \\
(0.88)\end{array}$ \\
\hline \multirow[t]{2}{*}{ Male defendant } & -0.718 & -0.438 \\
\hline & $(1.64)$ & $(0.95)$ \\
\hline \multirow[t]{2}{*}{ Evidentiary strength } & -0.101 & -0.063 \\
\hline & $(1.19)$ & $(0.67)$ \\
\hline \multirow[t]{2}{*}{ Constant } & $1.919 * *$ & 0.888 \\
\hline & $(2.83)$ & $(0.91)$ \\
\hline Observations & 295 & 279 \\
\hline Case types treatment & not accounted for & fixed effects \\
\hline Correctly classified & $59.0 \%$ & $60.6 \%$ \\
\hline Goodness of fit p-value & 0.962 & 0.434 \\
\hline
\end{tabular}

Note: NCSC data covering trials at four sites in 2000-2001. Table reports coefficients with t-statistics in parentheses; $\dagger$ indicates $\mathrm{p}<0.10, * \mathrm{p}<0.05, * * \mathrm{p}<0.01$. Goodnessof-fit p-value based on Hosmer-Lemeshow statistic with 10 groups.

counsel may be influenced to have clients testify depending on the strength of the evidence. But the judge and jury may react to the evidence in part on the basis of whether the defendant testified. We therefore explored separate models of not only whether a defendant testifying is associated with the strength of the evidence as reported by juries, but also whether the strength of the evidence, as reported by judges, is associated with whether a defendant testified. We found no significant association in either relation.

Table 7 reports regression models of the jury's learning about a defendant's prior criminal record. Model (1) does not account for type of case. Model (2) uses dummy variables to account for type of case. A test of the hypothesis that they are collectively equal to zero yields $\mathrm{p}=0.228$, though some case types are individually significant. Both models account for the sample stratification by site. ${ }^{78}$

The models again show a consistent pattern of only one factor having a substantial, statistically significant effect. A defendant's testifying is the only factor substantially and significantly contributing to whether the jury learned of the defendant's prior criminal record.

78 We also explored, but do not report, multilevel models to account for locale and type of case. The results do not materially differ from those reported here. See id. 
Similar models, using site-level fixed effects, do not materially differ from those reported here.

Table 7. Logistic Regression Models of Jury Learning of Criminal Record

\begin{tabular}{|l|c|c|}
\hline & $(1)$ & $(2)$ \\
\hline & \multicolumn{2}{|c|}{$\begin{array}{c}\text { Dependent variable }=\text { jury learned of } \\
\text { criminal record }(0=\text { no, } 1=\text { yes })\end{array}$} \\
\hline Defendant testified & $2.421^{* *}$ & $2.806^{* *}$ \\
\hline Minority defendant & $(6.36)$ & $(6.23)$ \\
\hline & 0.814 & 1.069 \\
\hline Male defendant & $(1.18)$ & $(1.19)$ \\
\hline & 1.287 & 0.942 \\
\hline Evidentiary strength & $(1.55)$ & $(1.04)$ \\
\hline & -0.133 & -0.169 \\
\hline Constant & $(1.04)$ & $(1.16)$ \\
\hline & $-3.747^{* *}$ & $-4.788^{* *}$ \\
\hline Observations & $(3.55)$ & $(3.10)$ \\
\hline Case types treatment & 223 & 210 \\
\hline Correctly classified & not accounted for & fixed effects \\
\hline Goodness of fit p-value & $74.9 \%$ & $79.1 \%$ \\
\hline
\end{tabular}

Note: NCSC data covering trials at four sites in 2000-2001. Table reports coefficients with $\mathrm{t}$-statistics in parentheses; $* *$ indicates $\mathrm{p}<0.01$. Goodness-of-fit $\mathrm{p}$-value based on Hosmer-Lemeshow statistic with 10 groups.

IV

The Effect of Juries' Learning of Criminal Records

Defendants presumably testify when they believe it promotes acquittal more than not testifying would. As shown in Part III, the decision whether to testify is significantly associated with the existence of a prior record. And the jury's learning of a defendant's prior record is significantly associated with whether that defendant testified. Table 4 shows that juries rarely learn of criminal records unless defendants testify. We now explore whether, for the cases of defendants with criminal records, juries' learning about criminal records is associated with whether they convict defendants.

Prior models of conviction using the data analyzed here found that the perceived strength of the evidence was the only consistent factor significantly associated with the probability of conviction, ${ }^{79}$ but

79 Eisenberg, Hannaford-Agor, Hans, Waters, Munsterman, Schwab \& Wells, supra note 54, at 197 tbl. 9 . 
those models did not include whether juries learned about criminal records. One study using these data reports no relation between learning of a criminal record and conviction. ${ }^{80}$ However, that study did not control for evidentiary strength.

Studies of jury behavior indicate that the strength of the evidence dominates decision making. Evidence strength is so powerful that it is difficult to study the influence of other factors. ${ }^{81}$ Indeed, Kalven and Zeisel determined that many factors affected jury decision making and caused juries to disagree with what the judge would have decided primarily in cases in which the evidence was closely divided. Jury researchers typically calibrate the evidence in their mock jury experiments so that the evidence is ambiguous and the independent variables have a chance to influence the verdict.

In our study of real juries, because jurors were asked about the strength of evidence, we can control for case strength using that measure. The question is whether juries' learning about criminal records influences conviction rates after accounting for their views of evidentiary strength.

\section{A. Evidentiary Strength, Conviction Rate, and Knowledge of Record}

Table 8 shows the relation between the jury's learning of a criminal record and conviction. As noted above, the sample is limited to cases with defendants who had prior criminal records. For defendants who testified, there was no meaningful difference in the overall conviction rate between cases in which juries learned of the criminal record and cases in which they did not. Similarly, for defendants who did not testify, no meaningful difference emerged between defendants with and without records. In addition, convictions rates did not noticeably differ between defendants who testified and those who did not. All four conviction rates were between $71 \%$ and $78 \%$.

80 See Givelber, supra note 48, at 1190.

81 See, e.g., John Guinther, The Jury in America 102 (1988) ("Juries are evidenceoriented . . .."); Sally Lloyd-Bostock, Law in Practice: Applications of Psychology to Legal Decision Making and Legal Skills 48 (1989) (“[T] he most important aspect of any case with very few exceptions tends to be the strength of the evidence.”); MichaEl J. Saks \& Reid Hastie, Social Psychology in Court 68 (Robert E. Krieger Publ'g Co. 1986) (1978) (" $[\mathrm{T}]$ he power of evidence is so well recognized by jury researchers that when studying processes other than evidence, they must calibrate the evidence to be moderate so that it leaves some variance to be influenced by the variables under study.”); Valerie P. Hans, The Jury's Response to Business and Corporate Wrongdoing, 52 Law \& Contemp. Probs. 177, 194 (1989) ("Typically the evidence . . d drives juror decisionmaking."); Christy A. Visher, Juror Decision Making: The Importance of Evidence, 11 LAw \& Hum. BeHAV. 1, 13-14 (1987) (emphasizing the importance of evidence in comparison to extralegal factors). But see Eisenberg, Hannaford-Agor, Hans, Waters, Munsterman, Schwab \& Wells, supra note 54, at 205 n.60 (finding juror characteristics associated with capital sentencing). 
Of course, the strength of the evidence against a defendant may confound the seemingly equivalent conviction rates and mask real differences. If evidence against a defendant is noticeably weaker in cases in which juries learned of convictions, knowledge of prior records may serve to bolster marginal evidence. Table 8 , therefore, also includes information about the strength of the evidence for each case category. The measure of evidentiary strength is based on jurors' reports. Using judges' reports about evidentiary strength (not reported here) does not materially change the results.

Table 8. Jury Knowledge of Prior Criminal Record And Conviction

\begin{tabular}{|c|c|c|c|}
\hline & Number not convicted & Number convicted & $\%$ convicted \\
\hline & (Evidence strength) & (Evidence strength) & (Evidence strength) \\
\hline DEFENDANT TESTIFIED & & & 76.6 \\
\hline Jury did not learn of record & 11 & 36 & $(4.86)$ \\
\hline Mean evidence strength & $(3.10)$ & $(5.40)$ & 77.8 \\
\hline Jury learned of record & 12 & 42 & $(4.48)$ \\
\hline Mean evidence strength & $(2.79)$ & $(4.96)$ & 71.4 \\
\hline DEFENDANT Did NOT TESTIFY & & & $(4.67)$ \\
\hline Jury did not learn of record & 32 & 80 & 72.7 \\
\hline Mean evidence strength & $(3.09)$ & $(5.30)$ & $(4.54)$ \\
\hline Jury learned of record & 3 & 8 & $(5.30)$ \\
\hline Mean evidence strength & $(2.53)$ & &
\end{tabular}

Note: NCSC data covering trials at four sites in 2000-2001. Sample is limited to cases with defendants who had criminal records. Strength of evidence is coded on a one-to-seven Likert scale with higher values indicating evidence more favorable to the prosecution.

As expected, substantial differences exist in perceived evidentiary strength between cases with convictions and acquittals. Evidentiary strength is naturally the most powerful factor explaining case outcomes. On the one-to-seven scale, evidentiary strength in cases with convictions clustered around five. Evidentiary strength in acquittals clustered around three. The question of interest here is whether juror knowledge of criminal records contributes to explaining those outcomes beyond the explanatory power of the evidentiary strength.

Figure 1 helps assess the influence of knowledge of a criminal record while accounting for evidentiary strength. The jurors' view of the evidence is averaged for each case and rounded to the nearest integer from one to seven. Thus, each case is assigned an evidentiary strength of one through seven. The conviction rate is computed at each of the integer values. The cases with the strongest perceived evidence values, six or seven, had nearly $100 \%$ conviction rates whether or not juries learned about criminal records.

Conviction rates for rounded evidentiary strength values less than four, below the middle of the Likert scale, show interesting variety. 
Figure 1. Conviction Rate as Function of: Evidentiary Strength \& Knowledge of Record

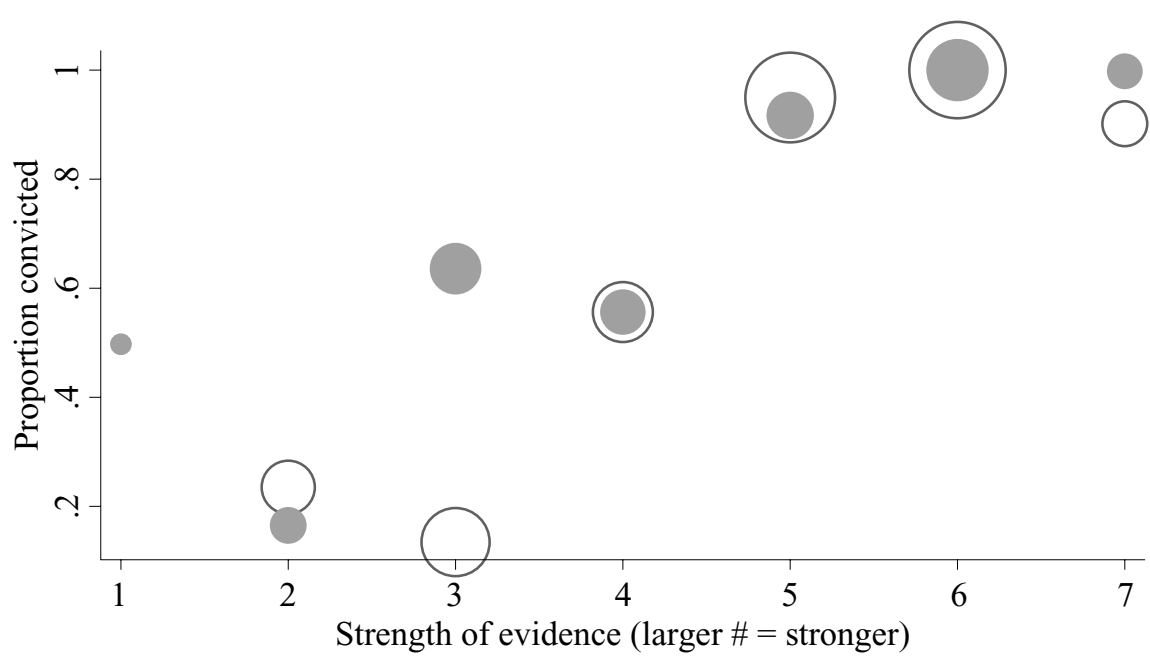

$\circ$ Jury did not know about record $\bullet$ Jury knew about record

Note: NCSC data covering trials at four sites in 2000-2001. Evidentiary strength on the $\mathrm{x}$ axis is rounded to the nearest integer value of the mean strength in a case as reported by multiple jurors. Conviction rates, reported on the y-axis, are computed separately for cases in which jurors did and did not learn of prior records and are computed separately for each value on the x-axis. Symbol sizes are proportionate to the number of cases comprising the observation. For example, there were only two cases with prior criminal records and evidentiary strength equal to one. Principal results of interest are the gap between cases with and without record at evidentiary strength equal to three and the absence of such a gap at other evidentiary strengths.

One quirk is the $50 \%$ conviction rate for evidentiary strength equal to one, the case with the weakest evidence favoring conviction. But, as the small size of the shaded circle for that evidentiary value suggests, this rate is based on only two cases and one conviction. Interestingly, the conviction was one in which the jury learned of a criminal record. ${ }^{82}$ The most striking conviction rate is for cases with evidence strength equal to three in which the jury learned about a criminal record. Despite the relatively weak evidence, the conviction rate exceeded $60 \%$, far greater than the rate for cases with evidentiary strength equal to three in which the jury did not learn about a criminal record, and far greater than the conviction rate for evidentiary

82 The case was in the Bronx, involved illegal drug sales, and had two counts. The judge predicted that the jury would find the defendant guilty on some charges and not guilty on others. The jury acquitted on one count and convicted on the other. The judge assigned the conviction an evidentiary strength of two but reported being "very satisfied" with the jury's decision. The jurors' report of low evidentiary strength was based on the report of only two jurors. Note that, as reported in Part II, the Bronx had a noticeably lower juror-response rate than the other sites. 
strength equal to two. Unlike the minuscule sample for evidentiary strength equal to one, the surprisingly high conviction rate at evidentiary strength three is based on eleven cases. A similar pattern, shown in Appendix Figure 1, emerges if one uses the judges' measure of evidentiary strength rather than the juries' measure. The distributions of perceived evidence strength differ for juries and judges. ${ }^{83}$ In line with this differential pattern, Appendix Figure 1 shows that the pattern shifts downward somewhat so that the key divergence between cases in which juries do and do not learn about a defendant's criminal record is now at the judge's evidentiary strength level of two.

\section{B. Regression Models of Conviction}

Regression models in Table 9 explore whether the pattern in Figure 1 survives more rigorous statistical modeling. The models seek to explore whether knowledge of past criminal record influences a dichotomous outcome, whether any conviction resulted. We again limit the sample to cases in which defendants have criminal records. The controls, which vary across models, include evidentiary strength, gender, minority status, and type of crime. ${ }^{84}$

The pattern across the regression models confirms the pattern suggested by Figure 1. Stratifying the data's evidentiary strength indicates that jury knowledge of prior criminal history is significantly associated with conviction in weak cases and not significantly associated with conviction in strong cases. The models in Table 9 control for evidentiary strength, account for county-level effects through dummy variables, and cluster standard errors by case type.

83 See Eisenberg, Hannaford-Agor, Hans, Waters, Munsterman, Schwab \& Wells, supra note 54 , at $186-89$ tbl.4, figs.1, 2.

84 For purposes of these models, DUI and attempted-murder convictions were included with the case type "Other" due to the lack of variation for these case types given the other variables in the models. We also ran (1) two-level random intercept logistic models with separate intercepts for each case type and county fixed effects and (2) three-level random intercept models with intercepts for case type and county. These models yield results similar to those in Table 9 except that, in the three-level model for the sample limited to evidentiary strength $>3.5$, the coefficients and standard errors appear to be unstably large. Other models, not reported here, employ systems of two equations. The goal in those models was to account for the endogeneity of juries' learning of past criminal history. The first equations modeled whether jurors learned of criminal record. As shown in Tables 4 and 7 above, this is largely a function of whether the defendant testified. The second equations model conviction after correcting for the nonrandom pattern of juries' learning about criminal history. We found that, measured by a standard model assessment criterion (the Akaike information criterion, see Gelman \& Hill, supra note 77, at 525), the second equations in multiequation models were inferior to similar single-equation models that did not include an adjustment. The extra parameter introduced by the adjustment is not worth the gain in explanatory power that accompanies adding an additional parameter. Models using fixed effects for case types are not satisfactory because of the reduced sample models' lack of variation. 
Table 9. Logistic Regression Models of Conviction

\begin{tabular}{|l|c|c|c|}
\hline & $(1)$ & $(2)$ & $(3)$ \\
\hline & \multicolumn{2}{|c|}{ Dependent variable = jury convicted (0=no, 1=yes) } \\
\hline & Full sample & Evidence strength $\leq 3.5$ & Evidence strength $>3.5$ \\
\hline Evidentiary strength & $1.705^{* *}$ & 0.411 & $2.272^{*}$ \\
\hline & $(7.41)$ & $(0.81)$ & $(2.20)$ \\
\hline Jury learned criminal history & 0.942 & $1.624^{*}$ & -0.116 \\
\hline & $(1.11)$ & $(2.52)$ & $(0.12)$ \\
\hline Site=Los Angeles & $1.317 \dagger$ & 1.666 & 1.615 \\
\hline & $(1.83)$ & $(1.24)$ & $(1.09)$ \\
\hline Site=Maricopa & $1.314 \dagger$ & 1.973 & 1.606 \\
\hline & $(1.77)$ & $(1.21)$ & $(1.40)$ \\
\hline Site=Bronx & $1.793^{*}$ & $2.439 \dagger$ & 1.190 \\
\hline & $(2.23)$ & $(1.83)$ & $(1.10)$ \\
\hline Site=D.C. (reference category) & & & $-9.325^{*}$ \\
\hline Constant & $-7.146^{* *}$ & $-4.658 \dagger$ & $(2.01)$ \\
\hline & $(6.80)$ & $(1.92)$ & 156 \\
\hline Observations & 214 & 58 & $92.3 \%$ \\
\hline Case types treatment & cluster & cluster & 0.014 \\
\hline Correctly classified & $89.7 \%$ & $74.1 \%$ & cluster \\
\hline Goodness of fit p-value & 0.388 & 0.411 & . \\
\hline
\end{tabular}

Note: NCSC data covering trials at four sites in 2000-2001. Table reports coefficients with $\mathrm{t}$ statistics in parentheses; $\dagger$ indicates $\mathrm{p}<0.10, * \mathrm{p}<0.05$. $* * \mathrm{p}<0.01$. Models cluster standard errors by case type and use county fixed effects. Goodness-of-fit p-value is based on HosmerLemeshow statistic with 10 groups.

Model (1) includes all cases involving a defendant with a criminal record. Although Model (1) shows no significant criminal record effects, the other two models show that this full-sample story is seriously incomplete. Model (2) limits the sample to cases with weak evidence against the defendant. According to the average of individual juror reports of evidentiary strength, these cases had evidentiary strength of less than or equal to 3.5 on the one-to-seven scale. This model shows that the evidentiary-strength variable does not approach statistical significance in weak cases. This is consistent with the non-monotonically increasing pattern of conviction rates at the low end of evidentiary strength in Figure 1. Thus, most of the contribution to the significance of the evidentiary-strength variable is from cases with strong evidence, those with average evidentiary strength exceeding 3.5. This is confirmed by the large statistically significant coefficients on the evidentiary-strength variable in the sample limited to strong cases, as shown in Model (3). Model (2) does show a substantial, significant, positive association between learning of a criminal record and conviction. This too is consistent with the separation of cases in which jurors did or did not learn of the defendant's criminal record in Figure 1. 
The magnitude of the effect of knowledge of criminal record can be strikingly large. In Model (2), in cases that round to evidentiary value three, the marginal effect of knowledge of criminal conviction in the District of Columbia is to increase the probability of conviction by 0.36 . The corresponding increase is 0.30 in Los Angeles, 0.32 in Maricopa, and 0.10 in the Bronx..$^{85}$ As the overall probability of conviction at evidentiary level three without a criminal record is just below $0.20,{ }^{86}$ the presence of a criminal record increases the probability of conviction from less than $20 \%$ to about $50 \%$ or greater. In contrast, at rounded evidentiary level four in Model (3), the marginal effect of knowledge of a criminal conviction is small and insignificant in all four jurisdictions.

Additional models that control for gender and minority status, not reported here, do not yield results materially different from those reported here. But reduced sample models that include these variables cannot include all observations because of lack of variation in outcome across gender and minority status. The small numbers of white defendants and female defendants, as shown in Tables 1 and 4 above, prevent systematic inclusion of these variables across the full range of models. Results are also not attributable to a single locale.

Together, these results suggest that in strong cases-cases that have crossed the jury's evidentiary threshold of 3.5-variations in evidentiary strength continue to contribute to the probability of conviction. The existence of a prior criminal record does not materially contribute to conviction probability. In weak cases, cases with evidence less than or equal to 3.5, the dominant tendency is not to convict. But, in the strongest of weak cases, the existence of a prior criminal record can prompt a jury to convict. The prior record effectively leverages the existing evidence over the threshold needed to support conviction.

The core results can be shown simply in Table 10, which contains the conviction rate for the bifurcated levels of evidentiary strength, further subdivided by whether the jury learned of the defendant's criminal record.

\section{Discussion of Results}

We now consider the results in light of the theoretical reasons in Part I suggesting why prior record is important. Subject to the limitations of a nonexperimental design, our findings most directly support the fourth theoretical basis for believing prior record to be important.

85 Similar probability increases occur at lower evidentiary-strength levels, but the weaker evidence in those cases presumably limits the power of a criminal record to result in a conviction.

$86 \quad$ See supra fig.1. 
Table 10. Jury Knowledge of Prior Criminal Record AND Conviction

\begin{tabular}{|c|c|c|c|}
\hline & Number not convicted & Number convicted & \% convicted \\
\hline EvidENCE STRENGTH $\leq 3.5$ & & & \\
\hline Jury did not learn of record & 32 & 7 & 18.0 \\
\hline Jury learned of record & 12 & 9 & $42.9 *$ \\
\hline EvidENCE STRENGTH $>3.5$ & & & \\
\hline Jury did not learn of record & 11 & 109 & 90.8 \\
\hline Jury learned of record & 3 & 41 & 93.2 \\
\hline
\end{tabular}

Note: Sample is limited to cases with defendants who had criminal records. Strength of evidence is coded on a one-to-seven Likert scale, with higher values indicating evidence more favorable to the prosecution. Strength of evidence is average for each case based on juror reports. For significance level, * indicates statistical significance at $<0.05$ using mid-p exact test.

The conviction threshold appears to differ for defendants with and without criminal records. As Figure 1 and the regression models suggest, jurors appear willing to convict on less strong other evidence if the defendant has a criminal past.

The results also help identify the cases in which the shifted conviction threshold has most effect. A prior record plays little role in cases with strong or even average (value four) evidence, hence the small differences in conviction rates at evidence values four through seven between cases with and without juror knowledge of criminal record information. Nor does prior criminal record often play an outcome-determinative role in cases with evidence too far below the conviction threshold of about four. Hence the small difference at evidence value two between cases with and without juror knowledge of criminal records and the low conviction rates for both classes of cases. But for cases with evidentiary value close to, but below, the threshold of four, a prior criminal record can lead to conviction.

One could view a prior record as "making up" for evidentiary deficiencies. Or, one might view the prior record as evidence tending to suggest guilt. Under either view, the prior record makes a difference. That the record effect occurs primarily in cases in which the evidence is not overwhelming resonates with Kalven and Zeisel's classic finding that extralegal factors have the most impact primarily in close, as opposed to clear, cases. ${ }^{87}$

One can also assess the theory that prior record changes the meaning of evidence rather than shifting the conviction threshold. As suggested earlier, jurors may internalize knowledge of a criminal record into an overall view of the case as having stronger evidence favoring conviction. We hypothesized on the basis of the experimental jury research that knowledge of criminal history could directly affect the jurors' (and even judges') perceptions of evidentiary strength. We

87 See Kalven \& Zeisel, supra note 40, at 133-35. 
also noted that the impact of criminal record on juror judgments about evidence might be difficult to detect because, if it operates as hypothesized, it would already be incorporated into jurors' perceptions of the strength of the case.

With that as a cautionary comment, the relation between evidentiary strength and knowledge of criminal record seems more consistent with the threshold theory. Cases in which jurors learned of criminal records tend to have slightly lower perceived evidentiary strength than cases in which jurors lacked knowledge of criminal records, as shown in Table 8 . When the defendant testified, cases ending in conviction had average evidentiary strength of 4.96 (knowledge of record) and 5.40 (no knowledge of record); cases ending in acquittal had average evidentiary strength of 2.79 (knowledge of record) and 3.10 (no knowledge of record). If knowledge of a criminal record changes the meaning of evidence towards conviction, it does so in a way that increases evidentiary strength merely to the level of, but not beyond, evidentiary strength in cases in which jurors do not learn of criminal records. Perhaps prosecutors viewed existence of prior convictions as warranting prosecution of otherwise weaker cases.

In addition to the lower conviction threshold, we also find evidence of a negative halo effect. Jurors were asked, on a one-to-seven scale, the degree of sympathy they had for defendants. In a regression model of the degree of sympathy as a function of knowledge of a criminal record, a statistically significant $(p=0.023)$ negative association existed between sympathy and record. In a model that includes evidentiary strength as an explanatory variable, the relation becomes more significant $(p=0.008)$. Results do not materially change if we also control for case type and defendant race and sex. But adding the degree of sympathy as an explanatory variable in close cases, those in Model (2) in Table 9, does not yield a statistically significant coefficient. Jurors may feel more negatively about defendants with criminal records, but that reduced respect does not help explain the conviction pattern in close cases.

With respect to the effect of prior record on credibility, we do not find evidence that criminal records affect defendant credibility. Jurors were asked to rate the believability of the defendant's evidence on a one-to-seven scale. In cases in which defendants testified, criminal record was not significantly associated with the degree of believability. This was so whether or not one controlled for jurors' perceptions of the strength of the evidence. This noneffect may of course be attributable to defendants' being selective about the cases in which they testified. In cases in which testifying would be most damaging to credibility, defendants may simply decline to testify. However, it is worth noting the convergence of this finding with the 
experimental research. In the jury experiments reviewed earlier that varied a defendant's criminal record, the evidence in the case and the other characteristics and testimony of the defendant were held constant. In those controlled circumstances, researchers did not typically find strong links between the presence of a criminal record and changes in the defendant's credibility.

The absence of an association between criminal record and credibility is deeply troubling given the theory underlying allowing impeachment based on a defendant's criminal record. ${ }^{88}$ In most instances, the justification for allowing the use of a prior criminal record is to facilitate assessing the defendant's credibility. ${ }^{89}$ Thus, "the government might show that the defendant had been convicted of a crime, to affect his credibility as a witness, but for no other purpose." 90 If, as our results and experimental results suggest, prior record affects case outcomes but not credibility, the historical justification for allowing the use of criminal records is unfounded.

\section{Conclusion}

Avoiding conviction of the innocent is a preeminent goal of the criminal justice system. ${ }^{91}$ Lord Patrick Devlin's oft-quoted statement captures much of the spirit underlying the jury-trial guarantee: "Trial by jury is not an instrument for getting at the truth; it is a process designed to make it as sure as possible that no innocent man is convicted." 92 As of this writing, over 200 post-conviction exonerations based on DNA evidence have been documented. ${ }^{93}$ The number of erroneous convictions is likely much higher because of the difficulty of establishing innocence in cases that do not involve DNA. ${ }^{94}$

Experimental and real-world data, as confirmed by this study, uniformly suggest that knowledge of defendants' prior records promotes conviction in close cases, those where one should be most concerned about erroneous convictions. The criminal-record effect could be even stronger than we have found in these analyses; the experimental work suggests that having a record for a similar offense creates the

88 We thank Geoffrey Stone for pointing this out.

89 See, e.g., Commonwealth v. Gorham, 99 Mass. 420, 21 (1868) ("The defendant ... offered himself as a witness, and the rules of evidence affecting the competency or credibility of witnesses were all applicable to him in that character.").

90 Commonwealth v. Bonner, 97 Mass. 587, 588 (1867) (describing the trial judge's ruling).

91 Givelber, supra note 48, at 1172 (stating that "[n]o one wants to participate in a practice that they believe routinely imprisons the innocent").

92 Lord Devlin, The Criminal Trial and Appeal in England, Address at the University of Chicago for the Third Dedicatory Conference (Jan. 1960), quoted in Kalven \& Zeisel, supra note 40, at 190 .

93 See The Innocence Project, supra note 8.

94 See Gross et al., supra note 8, at 524. 
most bias, and we had information only about the presence of a defendant's criminal record, not its type. Together, our results and experimental results indicate that the historical basis for allowing prior record evidence-to challenge the defendant's credibility-has little empirical support.

The enhanced conviction probability that prior record evidence supplies in close cases may well contribute to erroneous convictions. A recent analysis of DNA exonerations suggests that many erroneously convicted defendants refrain from testifying because they fear the negative consequences of having their criminal records made known to the jury; while at the same time, juries who learn of the criminal records of innocent defendants who do testify are likely biased by the record information..$^{95}$ This bias suggests the value of exploring the development of legal rules that encourage defendants, even those with criminal records, to testify. ${ }^{96}$ Although eliminating all testimony about prior criminal records is unrealistic, prosecutors making charging decisions and judges considering the prejudicial effect of prior records should take into account the dramatic effect that knowledge of criminal record can have in close cases. Similarly, criminal defense attorneys should think long and hard about having clients testify in what they believe juries might regard as close cases.

95 See Blume, supra note 3, at 490-91.

96 Jeffrey Bellin, Improving the Reliability of Criminal Trials Through Legal Rules That Encourage Defendants to Testify, 76 U. CIN. L. REv. 851, 882-96 (2008) (proposing legal reforms that arguably would make it more attractive for defendants with criminal records to testify at trial by, for example, prohibiting all mention of prior convictions or allowing in limine motions to exclude prior-conviction impeachment in exchange for the defendant's commitment to testify). 
ApPENDIX

Appendix Figure 1.

Conviction Rate as Function of:

Evidentiary Strength (Per Judge) \&

KNOWLEDGE OF RECORD

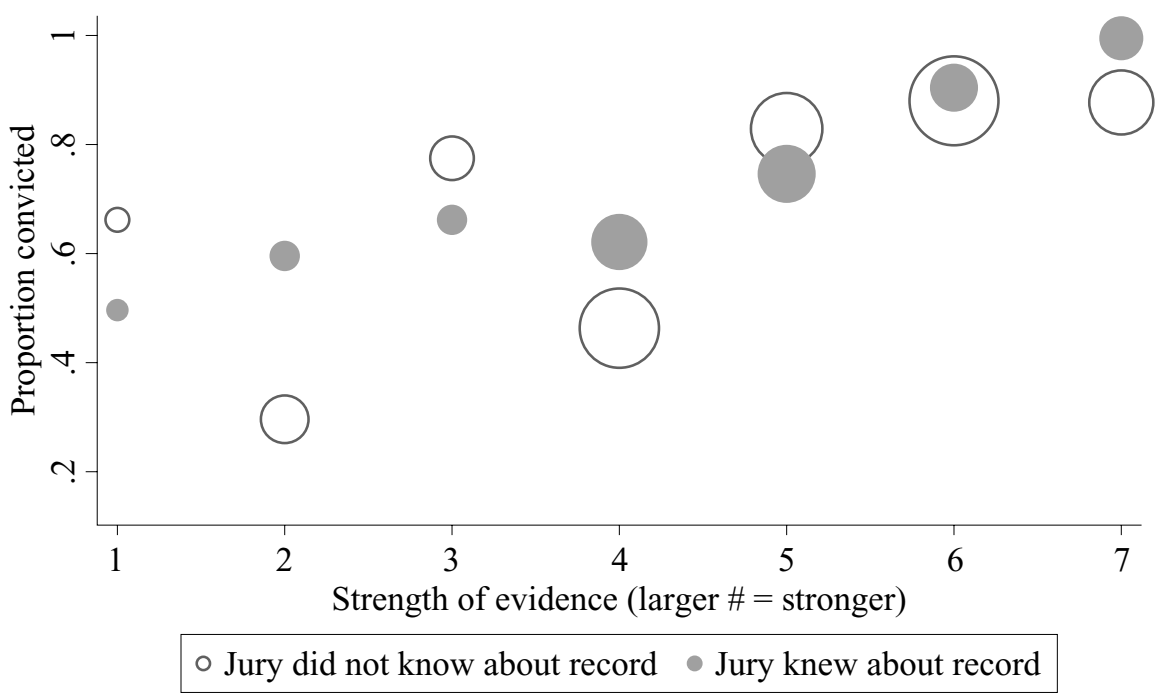

